\title{
Unødig lang sagsbehandlingstid i danske straffesager:
}

Uformel straf før dom ${ }^{1}$

Af Kasper Jørgensen, stud. soc. i kriminologi, AAU og Annette Olesen, ph.d., lektor AAU²

\begin{abstract}
For many years the Danish criminal justice system has been criticized for its drawn out handling of criminal cases - which is not only problematic for the victim's sense of justice, but is also a violation of the defendant's civil rights. It is nevertheless surprising how little we know about the implications for those who are forced to wait an unreasonably long time for trial, especially for those who are not remanded into custody. This article uses a socio-legal perspective to explore the time before conviction for defendants who must continue to live their everyday lives while awaiting decisions. Based on interviews $(n=45)$ and judicial decisions we show that the interviewees awaiting their trial are trapped in a powerless position and are unable to take positive steps forward in their lives. Furthermore, the article shows that experiencing a drawn-out trial date has a negative influence on these citizens' attachment to society even before their conviction by exposing them to social barriers similar to those faced by ex-convicts who have already served their time.
\end{abstract}

Keywords:

Penal subjectivism, criminal cases, processing time, waiting time, powerlessness

Uformel straf, straffesager, sagsbehandlingstider, ventetid, magtesløshed

\section{Introduktion}

Der er en grund til at det historiske torturinstrument pinebænk, hvor et menneske blev fastspændt og udsat for pinsel, er blevet en nutidig betegnelse for en situation, hvor man lader et menneske forblive i uvished. For vi kender det alle sammen: Følelsen af at blive holdt på pinebænken. Følelsen efter vi er gået for vidt, for langt, har brudt normen og overskredet et andet menneskes grænse. Nu venter vi bare på reaktionen. Vi ved ikke, hvornår reaktionen

1. Title in English: Unnecessarily long processing times in Danish criminal cases: the hidden punishments before conviction

2. Vi vil gerne takke de anonyme fagfællebedømmere for deres kommentarer. 
kommer. Vi ved ikke, hvor voldsom reaktionen bliver. Ventetiden er ofte uudholdelig, men der er intet andet at gøre end at vente, fastholdt i uvisheden. Måske på et voldsomt vredesudbrud, måske en belærende opsang eller noget helt tredje? Det er svært at forestille sig, at noget kan være værre end at vente uden at vide, hvad man venter på. Ikke desto mindre er det denne symbolske pinebænk, vi henviser mange sigtede ${ }^{3}$ til, når de venter på dom i en straffesag. I Danmark har vi i en længere periode haft lange sagsbehandlingstider i straffesager, hvilket medfører, at tiden på pinebænken kan strække sig gevaldigt og gribe ind i de sigtedes livssituation. Formålet med denne artikel er derfor, ud fra en bred forståelse af straf, at belyse hvorledes sigtede oplever ventetiden i frihed frem til dom og yderligere at problematisere den aktuelle tilgang til de unødigt lange sagsbehandlingstider i Danmark.

Artiklen består af tre overordnede dele; I forste del bliver problemstillingen vedrørende de unødigt lange sagsbehandlingstider aktualiseret og kontekstualiseret $\mathrm{i}$ et baggrundafsnit. Herefter udfoldes nyere strafforståelse, der udgør det teoretiske afsæt, og som har til formål at udfordre den dualistiske forståelse af formel og uformel straf. Derefter beskrives artiklens datagrundlag og metode. Anden del belyser dels den aktuelle retstilstand for sagsbehandlingstider i danske straffesager, og dels den uformelle straf sigtede oplever som egne mentale barrierer samt sociale og fysiske barrierer fra det omkringliggende samfund. I den tredje del anlægges et kritisk blik på de initiativer, der iværksættes for at nedbringe sagsbehandlingstiden i straffesager. Afsnittet afrundes med nogle konkluderende bemærkninger.

\section{Baggrund}

I 2012 tog Rigsrevisionen initiativ til at undersøge, hvorvidt Justitsministeriet levede op til lovgivningskrav om at behandle straffesager med den fornødne hurtighed. Kortlægningen viste, at en straffesags gennemsnitlige behandlingstid fra anmeldelse til påbegyndt afsoning i 2012 var på 433 dage, med et spænd fra 287 til 714 dage, hvilket blev vurderet til ikke at leve op til gældende bestemmelser. Ifølge Rigsrevisionen kunne de lange sagsbehandlingstider bl.a. begrundes med besværlige arbejdsgange imellem de implicerede myndigheder, ligesom der primært havde været fokuseret på sagsbehandlingstiderne i de enkelte myndigheder fremfor på tværs af myndighederne. Justitsministeriet blev derfor pålagt at sætte fokus på området og udarbejde tiltag for at nedbringe den samlede sagsbehandlingstid (Rigsrevisionen 2014). Rigsrevisionen udkom i 2017 med det første opfølgningsnotat, hvor det blev vurderet, at arbejdet med straffesagskæden i det tværsektorielle myndighedsarbejde var blevet styrket, men den gennemsnitlige sagsbehandlingstid

3. For at øge læsevenligheden anvender vi igennem hele artiklen 'sigtet' som fællesbetegnelse for sigtet og tiltalt, selvom artiklen fremhæver forskellige faser af det straffeprocessuelle forløb. 
levede forsat ikke op til gældende bestemmelser (Rigsrevisionen 2017). I andet og afsluttende opfølgningsnotat fra 2019 fandt Rigsrevisionen det tilfredsstillende, at Justitsministeriet i 2018 lancerede initiativpakken Hurtigere vej fra forbrydelse til fængsel, der havde til formål at nedbringe sagsbehandlingstiden i den samlede straffesagskæde. Rigsrevisionen konkluderede dog, at der vil gå adskillige år, før situationen lever op til gældende bestemmelser. Trods politisk årvågenhed var den gennemsnitlige sagsbehandlingstid i 2019 blevet marginalt længere end i 2012 og lød på 439 dage. ${ }^{4}$ Hertil skal nævnes, at perioden fra dom til påbegyndt afsoning rent faktisk var faldende i 2019, det er således perioden fra anmeldelse til dom, der er blevet længere.

I de politiske drøftelser om de lange sagsbehandlingstider er det sjældent sigtedes livssituation, der er i fokus, men derimod offeret og den samfundsmæssige signalværdi ved hurtig og konsekvent eksekvering af straf. Sigtedes livssituation og ventetiden fra anmeldelse til dom er heller ikke emner, der fylder meget i den kriminologiske litteratur. Der er ganske vist flere fængselsstudier, der belyser, hvordan tiden fra indsættelse til løsladelse bliver oplevet af indsatte (se fx Peel; Shamas; Sexton; Crewe et. al.; Olesen) samt studier, der behandler tiden som varetægtsfængslet (se fx Freeman \& Seymour; Smith 2014; Mesmaecker; Turnbull; Orjiakor et. al.). Flere af studierne om varetægtsfængsling lægger vægt på, at den ukendte dato for domsafsigelse er psykisk nedslidende, og ventetiden før dom som varetægtsfængslet opleves som 'limbo time', 'a waiting game' og 'a seemingly limitless sentence to unsentenced time' (Neustatter). Et af de få skandinaviske studier, der empirisk belyser oplevelsen af ventetid uden for fængselsmurene, er Laursen et al.'s (2019) studie, der belyser domfældte i Norge, som venter på at afsone. Tiden i 'fængselskøen' indregnes ikke i strafudmålingen, men studiet finder, at ventetiden inden afsoning, og uvisheden der følger, ofte er vanskeligere og mere mentalt tyngende end selve frihedsberøvelsen. I tråd med Neustatter (2002) beskriver de domfældte i Lauersen et al.'s studie perioden som et 'vacuum' og en 'sentence before the sentence'. De omtalte studier undersøger ganske vist ventetid i straffesystemet, men ikke hvordan sigtede, der ikke er varetægtsfængslet, oplever ventetiden under straffesagens behandling og frem til dom. Artiklens fokus vil derfor være på tiden fra anmeldelse til dom, da det dels er denne periode, der er blevet længere i de danske straffesager, og dels denne periode, der er særligt underbelyst i den kriminologiske litteratur.

\section{Nyere strafforståelse}

Straf kan med få ord beskrives som et onde og en reaktion (Christie, s. 302). At det er et onde at blive holdt på pinebænken inden dom, kan de

4. Sagsbehandlingstiden i dage fra anmeldelse til afsoning for sager afsluttet med afsoning fordelt på procestrin - alle forhold (Opgørelse udarbejdet af Koncernstyringskontoret, notat modtaget af Justitsministeriet 23/11-20). 
fleste nok blive enige om, men ventetiden bliver ikke i juridisk forstand betragtet som en del af den straffende reaktion. Derfor sondrer vi mellem formel og uformel straf. Domstolene idømmer den formelle straf, som i udgangspunktet er ens for alle, mens den uformelle straf ikke er en del af den straf, domstolene idømmer, og afhænger af pågældendes livssituation. Den uformelle straf er således den straf, der følger af at være blevet idømt en formel straf. Uformel straf kan betegnes, som forskellen på de sociale, økonomiske og beskæftigelsesforhold som man kunne have haft som ikke-straffet borger, og de sociale, økonomiske og beskæftigelsesforhold man har som straffet borger (Tranæs og Geerdsen; Olesen). Uformel straf bliver som udgangspunkt betragtet som noget, der er affødt af den formelle straf, men i nærværende studie vil vi belyse, hvordan uformel straf allerede kan indtræde før den formelle straf. Til at behandle og belyse, hvorledes straffesagens sagsbehandlingstid indvirker negativt på sigtedes livssituation, vil vi tage afsæt i Hayes' forståelse af straf.

Hayes argumenterer for, at den formelle strafforståelse ${ }^{5}$ skjuler en betydelig virkning af straffen, men tilføjer samtidig, at den uformelle strafforståelse heller ikke må stå alene, da kompleksiteten i den straffedes liv vil have betydning for dennes strafbevidsthed (Hayes, s. 238). Ud fra denne betragtning forsøger Hayes at gøre op med den klassiske sondring mellem formel og uformel straf, og i stedet for at svare på 'hvad der egentlig tæller som straf?' bliver der inden for genren af nyere strafforståelse argumenteret for én samlet forståelsesramme, hvor den uformelle straf behandles og belyses ud fra dens relation til den formelle straf (Hayes, s. 237). Hertil præsenterer Hayes en cirkelmodel over 'pain' (pine) ved straf, der indbefatter fire forskellige typer af pine: 'direct pains', 'oblique pains', 'contextual pains' og 'unrelated pains.' Cirkelmodellen inddeler de forskellige typer af pine i relation til, hvor tæt de pinefulde konsekvenser ved straffen er på statens tilsigtede strafreaktion. Hermed bliver det muligt at indfange og afdække straf som et empirisk begreb (Hayes, s. 240). Direkte pine ved straf udgør den inderste kerne i Hayes' cirkelmodel. I cirklens periferi - men fortsat i relation til straffens intensitet - placerer Hayes kontekstuel pine, som består af en lang række delvist uforudsigelige og utilsigtede virkninger af straffen. Denne pine dækker over handlinger og reaktioner fra grupper (familie, venner, offentlige myndigheder, private virksomheder og frivillige organisationer - ja tilmed den straffede selv), der ikke repræsenterer retssystemet og ikke i formel forstand kan gennemføre straffende reaktioner (Hayes, s. 240). Det er denne kontekstuelle pine, vi i det følgende vil behandle indgående.

Med afsæt i nyere strafforståelse vil straffesagers unødigt lange sagsbehandlingstider blive belyst som et samlet samfundsjuridisk fænomen bestående af den retlige forståelse herfor og den oplevede konsekvens heraf. Formålet med at anvende Hayes cirkelmodel for pine ved straf er at

5. Hayes anvender begreberne 'penal objectivism' og 'penal subjectivism'. I nærværende oversættes disse til formel og uformel straf. 
kombinere 'law-on-the-books', 'law-in-action' og 'penal consciousness' og bidrage med en nuanceret forståelse af sammenspillet mellem det sociale liv og strafferetten.

\section{Data og metode}

Analysen bygger på to kvalitative datamaterialer. Af det ene studie er der inddraget en retsdogmatisk dokumentanalyse af systematisk udvalgte retskilder og fire interview, der specifikt fokuserer på ventetiden fra sigtelse til dom (Jørgensen et al.). Fra det andet studie er der inddraget 41 interview, der har et bredere perspektiv, og belyser tiden $f ø r$, under og efter afsoning (Olesen). De tilsammen 45 interview varede ca. 1-3 timer. De interviewede er alle mænd, og 42 af dem er flergangsdømte, der har erfaringer fra sigtelser, ventetid før dom i frihed, varetægtsfængslinger, fængselsafsoninger og frifindelser. Tre af de interviewede havde kun været sigtet i en sag, hvoraf én var blevet dømt og to frifundet. I det følgende henviser vi til de interviewede som sigtede, da de i deres beretninger ikke sondrer mellem at være sigtet eller tiltalt, men derimod omtaler sagsbehandlingstiden som en sammenhængende periode fra sigtelse til dom. Interviewene er tematisk kodet efter Hayes cirkelmodel (2018), og materialet, der afdækker den kontekstuelle pine, der har en relation til straffesagers lange sagsbehandlingstid, udgør det empiriske grundlag for analysen.

Det skaber grundlag for metodisk refleksion, at det er de interviewedes forudgående oplevelser fra ventetiden i frihed før dom, der fokuseres på, og hovedparten af de interviewede har omfattende erfaring med straffesystemet. Den usikkerhed og det spændingsmoment, som de sigtede lever i, mens de venter på dom, gør sig nemlig ikke længere gældende, når de efterfølgende beretter om deres oplevelser herom, og deres beretninger vil ofte følge en ordnet rækkefølge med klare handlingsudvekslinger og efterrationaliseringer (se Merry; Bourdieu). Tiden indvirker således på de interviewedes fortællinger og derved også på empirien. Et eksempel herpå er de interviewedes beskrivelser af, hvordan de er blevet kompenseret for unødig lang sagsbehandlingstid. De påpeger, at kompensationen er vilkårlig og uafhængig af den pine, som ventetiden har påført dem. Oplevelsen af ikke at blive tilstrækkelig kompenseret vil angiveligt afspejle sig i den måde, hvorpå de interviewede beretter om deres oplevelser fra ventetiden før dom. På tilsvarende vis har det betydning, at størstedelen af de interviewede er flergangsdømte, da de tidligere har skulle navigere i pressede situationer og stifte bekendtskab med straffesystemet. Dette indvirker på deres oplevelser af tiden før dom. Et eksempel herpå er, at flere af de interviewede, der havde været varetægtsfængslet, sammenlignede tiden fra varetægtsfængsling med tiden i frihed før dom. En sammenligning som de få førstegangssigtede i datamaterialet ikke 
kunne foretage. Med disse metodiske udfordringer for øje vil vi i det følgende belyse sigtedes oplevelser i tidsperioden fra anmeldelse til dom.

\section{Straffesagers unødigt lange sagsbehandlingstider}

For at rammesætte den uformelle straf som sigtede møder under sagsbehandlingen af deres straffesag, vil vi kort gennemgå reglerne vedrørende straffesagers sagsbehandlingstid og beskrive, hvilke forhold der vægtes, når retten tager stilling til, om der skal kompenseres for unødig lang sagsbehandlingstid.

Reglerne for at fremme straffesagsbehandling

En straffesags sagsbehandlingsperiode dækker over to faser. Den ene går fra anmeldelse til anklagemyndighedens afgørelse af tiltalespørgsmålet (efterforskningsfasen), og den anden går fra anklagemyndighedens tiltalerejsning og frem til, at sagen er endelig afgjort ved domstolene.

Med Danmarks forpligtelser til Den Europæiske Menneskerettighedskonvention (EMRK) er enhver borger, der er sigtet af en dansk domstol, berettiget til at få sin straffesag for retten inden for rimelig tid. ${ }^{6}$ Der foreligger dog ikke nogen absolut frist for 'rimelig tid', men det fremgår, at straffesager skal behandles uden unødige ophold, og utilstrækkelige ressourcer ikke i sig selv er en begrundelse for, at kravet om rimelige sagsbehandlingstider kan afviges. ${ }^{7}$ Bestemmelsen kommer til udtryk i den danske retsplejelov, hvoraf politi, anklagemyndighed m.fl. er forpligtet til at fremme efterforskningsfasen "(...) med den hurtighed, som sagens beskaffenhed tillader det." ${ }^{8}$ På tilsvarende vis er domstolene forpligtet til at fremme hovedforhandlingen »(...) med den hurtighed, som dens beskaffenhed tillader og kræver det. ( $^{9}$ | overensstemmelse med EMRK er Danmark ikke forpligtet til at fastsætte en absolut frist for straffesagers sagsbehandlingstider, hvorved der heller ikke fremgår nogen frist af retsplejelovens bestemmelser, da bestemmelserne bl.a. tager højde for sagens kompleksitet (Toftegaard Nielsen, s. 43; Lorenzen et al., s. 259ff). Hvis retten finder, at der er sket en overtrædelse af konventionens bestemmelser, vil domstolene normalt kompensere domfældte. ${ }^{10}$ Dette kommer til udtryk i den danske straffelov, hvor det »ved straffens fastsættelse i almindelighed [kan] indgå som formildende omstændighed, at straffesagen mod gerningsmanden ikke er afgjort indenfor en rimelig tid, uden at det kan bebrejdes gerningsmanden «. ${ }^{11}$ Grundlaget for kompensation beror således

6. EMRK. art. 6. stk. 1.

7. Se fx EMD, Santilli mod Italien, dom af 19. februar 1991, app. nr. 11634/85, pr. 20.

8. Rpl. § 96, stk. 2 (lbk. 1445/2020).

9. Rpl. §843 a.

10. EMRK. art. 41.

11. Strfl. § 82, nr. 13 (lbk. 1650/2020). 
på rettens egen konkrete vurdering af straffesagens sagsbehandlingstid, hvor sagens karakter, kompleksitet samt tiltaltes og myndighedernes adfærd ligeledes vægtes (Toftegaard Nielsen, kap. 90). Der er derfor ikke i alle sager, hvor der har været tale om lang sagsbehandlingstid, grundlag for kompensation. Omvendt vil kortere sagsbehandlingstider afhængig af sagens konkrete omstændigheder kunne medføre en kompensation, hvis der ikke kan påvises særlige forhold i sagen, som kan begrunde sagsbehandlingstidens længe. ${ }^{12}$ Hvis retten finder tiltalte skyldig, så har en overtrædelse af bestemmelsen om rimelig sagsbehandlingstid konkret medført, at der er udmålt lavere straf i form af betinget straf, strafrabat eller strafbortfald, og/eller at statskassen er blevet pålagt at betale sagens omkostninger (Institut for Menneskerettigheder, s. 35). Hvis retten derimod frifinder tiltalte, kan retten anmodes om at kompensere for uberettiget langvarig sigtelse, hvilket i praksis sker efter fastsatte takster. ${ }^{13}$

\section{Sigtedes mentale barrierer udviklet under straffesagens lange sagsbehandlingstid}

Der er som hovedregel ingen formelle krav til de sigtede, som ikke er frihedsberøvet under sagsbehandlingen af en straffesag. Der er heller ingen af de interviewede, som oplever at blive udelukket fra hverdagsaktiviteter eller blive mødt med særlige krav under sagsbehandlingsperioden. Det er derfor tankevækkende, at det i overvejende grad er sigtedes egne reaktioner på den langvarige behandling fra anmeldelse til dom, der gør tiden særligt byrdefuld.

En sigtet, vi kalder John, tænker tilbage på de gange, han har afventet dom i en straffesag: "Altså om man havde været varetægtsfængslet eller ikke varetægtsfængslet, så havde det stadig været det samme. Du har ikke en anelse om, hvad der vil ske. Det er kun rammerne, der er forskellige«. Der er væsentlig forskel på, om man er frihedsberøvet eller blot føler sig (friheds) begrænset under sagsbehandlingen af ens straffesag. Trods denne betydelige forskel påpeger flere sigtede, der har oplevet ventetiden inden dom både i og uden for Kriminalforsorgens institutioner, at der i praksis ikke er den store forskel. For mange af de sigtede er det ikke de fysiske rammer, der gør sagsbehandlingsperioden psykisk nedslidende, men derimod følelsen af at blive holdt på uvishedens pinebænk.

Det er helt gennemgående for de interviewedes beretninger, at straffesagens sagsbehandlingsperiode er præget af usikkerhed, hvilket påvirker deres tilværelse på forskellige måder alt afhængig af, hvordan de håndterer det psykiske pres, de er underlagt (se Freeman og Seymour; Smith 2014). Den unge Valdemar eksemplificerer, hvordan usikkerheden, der følger af den

12. Besvarelse af spørgsmål nr. 72 af 14. oktober 2019 fra Folketingets Retsudvalg til justitsministeren.

13. Rpl. § 1018. 
lange sagsbehandlingsperiode, kan have vidtrækkende mentale konsekvenser. Valdemar isolerer sig fra resten af samfundet i sin etværelseslejlighed kun afbrudt af enkelte gåture: "Den [usikkerheden] kom nok mest til udtryk ved min selvisolering. Jeg var ikke særlig social aktiv, jeg holdt mig væk fra folk. Jeg havde heller ikke lyst til at møde nye mennesker eller danne nye venskaber på det tidspunkt«. For Valdemar tog lejligheden mere og mere form af at være en fængselscelle, og han levede i selvisolation i grænselandet mellem fri og ufri, hvilket kan betragtes som en ubevidst mental forberedelse på det ukendte og den ensomhed, der potentielt venter (se Crewe). Reduceringen eller afviklingen af det sociale liv eksemplificerer, hvordan nogle sigtede forandrede sig under ventetiden inden dom og indrettede deres tilværelse, så den mindede om en slags 'kvasi-frihedsberøvet' (se Comfort). Karl, der har mange domme bag sig, beskriver, hvordan ventetiden før og efter frihedsberøvelsen smelter sammen: „Jeg har altid siddet $i$ fængsel (...) jeg har ventet på at afsone og siddet i fængsel hele tiden.« De sigtede, der afventer deres dom i frihed, føler sig således ligesom de indsatte på mange måder låst fast i tid og sted. Sarat (1990, s. 342-343) bemærker om anvendelse af ventetid som magtapparat: »In that waiting they are frozen in time as if time itself were frozen; power defines whose time is valued and whose time is valueless." Ventetid gennemsyrer fængselslivet (Freeman og Seymour), men det står i skærende kontrast til den tidsforståelse, der kendetegner samfundet uden for fængslet. De sigtede kan således betragtes som 'fanget' i ventetiden $i$ frihed.

Netop denne oplevelse af mentalt at være fastlåst beskriver Bastian således »(...) det var som om, mit liv i fem år bare gik lidt i stå. Det har det gjort mange gange med mine sager, hvor det er trukket ud, og man har gået og ventet $i$ mange år, før man bliver dømt.« En anden sigtet beretter om den følelse, der rammer ham, og følger ham i forbindelse med en ny sigtelse: »Jeg bliver bare pisse bange, og jeg ser ligesom bare hjælpeløst til, mens vores [familiens] liv langsomt går i stå igen« (Emil). Da de sigtede som sagt ikke er frihedsberøvet under sagsbehandlingsperioden, så bærer deres oplevelse af magtesløshed generelt præg af, at de mentalt føler sig fastlåst i en position uden handlemuligheder. Ifølge flere af de interviewede er denne magtesløshed affødt af, at de ikke kan gennemskue fremtiden, men alligevel bekymrer sig om alle de ubekendte forhold, der måtte møde dem (se Laursen et al.; Hulley et al.). Hertil bemærker John: »Jeg har jo ikke rigtig kunnet starte med at få lavet nogle børn, uden at jeg vidste, hvad der ligesom skulle ske i sagen jo. Det synes jeg ikke, jeg kunne tillade mig. Hvis jeg skulle ind og sidde i spjældet og have et barn på 2-3 år, der skulle spørge, hvor far var henne? Det ville jeg ikke«. For at få greb om den magtesløse position de sigtede befinder sig i og håndtere den uigennemskuelige fremtid, nævner de flere forskellige copingstrategier. En af disse er ikke at investere i deres eget liv og afstå fra at indlede romantiske forhold, stifte familie, etc. (se Mattingly). De sigtede forsøger på den måde at beskytte dem selv fra at miste mere, end de allerede har mistet. Copingstrategien betyder dog, at de mister muligheden for at leve frit under 
straffesagens sagsbehandlingsperiode. En anden copingstrategi anvendt af flere af de interviewede gik ud på, at skærme sig mod uvisheden ved at fokusere på hverdagens mest nødvendige gøremål og således leve en dag ad gangen. En tilsvarende tilgang er blevet identificeret blandt langtidsfanger i deres forsøg på at tilpasse sig fængselsmiljøet (Crewe et al.).

\section{Sociale og fysiske barrierer i mødet med det omkringliggende samfund}

Den venteposition, som de sigtede oplever at være fastlåst i før dom, forgrener sig på forskellig vis til familien, arbejdspladsen og det offentlige system. Netop i den sigtedes møde med det offentlige system, får vi det tydeligste billede af, hvordan den sigtedes venteposition rækker langt ud over strafferettens område. Flere af de sigtede er på forskellig vis afhængige af hjælp fra det offentlige. Uafhængigt af hvilken hjælp der er tale om, bidrager de interviewede til en fælles fortælling om, at de uafklarede forhold, deres verserende straffesag medfører, betyder, at de er 'uden for kategori' i det offentlige system. Valdemar beskriver det således: „du står ligesom en almindelig borger med samme rettigheder (...) men de [kommunen] kan ikke lave noget længere forløb, fordi der er så stor uvished om, hvad der kommer til at ske (...) du står i en mærkelig position i systemet. Jeg ved ikke, om man står registeret sådan, men det er sådan lidt, det gør det lidt mere besværligt det hele.« De sigtede betegner deres plads i systemet som en slags »ingenmandsland« (Lukas). De er hverken rigtigt frie eller dømt, og de oplever at få adskillige afslag på alt fra længerevarende indsatser, der kunne have gavnet deres livssituation i ventetiden og på akutte problemer som $\mathrm{fx}$ hjemløshed. Ventepositionen ophører ved domsafsigelsen, hvor de interviewede med erfaringer fra forudgående straffesager mærker en tydelig forskel på at bevæge sig fra sigtet (uden for kategori) til dømt. Deres erfaringer tyder på, at alting bliver meget nemmere, når det offentlige har en konkret tidsplan for afsoning og løsladelse at forholde sig til. Konsekvenserne ved at være 'uden for kategori' i det offentlige system medfører ikke blot komplikationer hos den sigtede, men påvirker naturligvis også de pårørende.

Den påpasselighed, de sigtede møder hos de offentlige myndigheder, går igen på arbejdsmarkedet. Hvor det primært er de sigtedes uafklarede forhold, der lammer de offentlige myndigheder, så bunder påpasseligheden hos arbejdsgivere og kollegaer også i de sigtedes usikre fremtid, men mest af alt er det skyldsspørgsmålet, der trænger sig på og ofte overdøver selv gode arbejdsrelationer. Det betyder, at flere af de interviewede bliver afskediget, selvom deres verserende sag ikke relaterer sig til deres erhverv. Alfred, som ikke tidligere har stiftet bekendtskab med straffesystemet, fortæller herom: »de kunne jo ikke sætte en plet på noget som helst af det, jeg har lavet, altså mit arbejde eller noget (...) Men hvis tilliden ikke er der længere, så er der 
heller ikke nogen arbejdsrelation." Ifølge flere af de sigtede er det ikke blot deres arbejdsgivere og kollegaer, der møder dem med påpasselighed og mistillid, det samme gør sig gældende for de arbejdspladser, de søger ansættelse hos under deres straffesags behandling, hvis de selv eller en anden informerer arbejdspladsen om deres verserende straffesag (se Albrigt et al.; Martinez). Arbejdsmarkedets reaktioner mod dem oplever de som fordømmelse og stempling uden stillingtagen til, at deres straffesag er uafsluttet. Den eksklusion, de tre interviewede, der ikke tidligere har været sigtet i en straffesag oplever på arbejdsmarkedet, kan på flere måder sammenlignes med den, domfældte med en plettet straffeattest bliver mødt med (Pager et al.; Raphael; Sheppard \& Ricciardelli).

Oplevelsen af ikke at være værd - eller ligefrem farlig - 'at investere i' gennemsyrer de sigtedes fortællinger fra både arbejdsmarkedet og familielivet. Elias beskriver eksempelvis, hvordan hans kone efter sigtelsen tvivler på ham og "stiller en masse kritiske spørgsmål hele tiden (...) men jeg er ikke sådan en, der render rundt og snyder eller lyver«. Den usikkerhed, som flere sigtede oplever fra deres partneres side, skal relateres til den psykisk ustabile og praktisk udfordrende situation, parrene gennemlever under straffesagen, da partnerne ligesom de sigtede erfarer, hvordan deres privatliv og nogle gange også økonomi er låst fast til straffesagen. Erkendelsen af, at pinen forbundet med straffesagen forgrener sig til familien, betyder, at flere af de sigtede - ud over usikkerhed, uvished, stress og magtesløshed - også bliver tynget af en dårlig samvittighed, skam og skyldfølelse, der følger af at påføre deres nærmeste smerte. Flere af de sigtede oplever således både at være under anklage i straffesystemet og i familien, og begge steder er deres handlemuligheder yderst begrænsede. De interviewedes oplevelse af at holde deres partnere som gidsler under ventetiden og blive mødt af partnernes mistillid bevirker, at flere forhold brister under de verserende straffesager. Det er ganske tankevækkende, at flere af de sociale barrierer, de sigtede oplever, på mange måder kan sidestilles med dem, der møder indsatte og løsladte (se Kotova; Sheppard \& Ricciardelli; Keene et al.).

\section{Kompensation for straffesagens unødigt lange sagsbehandlingstid}

Sagsbehandlingstiden varierede ganske meget, men mange af de interviewede havde erfaret årelange forløb, og i flere tilfælde var der gået mellem 4-10 år, før de havde modtaget en dom. Flere af de interviewede havde også erfaret at blive frifundet helt eller delvist. Der er således flere, der har modtaget forskellige former for kompensation for den unødigt lange sagsbehandlingstid og for uberettiget langvarig sigtelse. Kompensationen opvejer dog kun sjældent den pine, de sigtede, der har ventet i frihed, er blevet påført. Det medfører, at sagsbehandlingstiden udgør en uformel straf i sig selv, og 
for flere en langt hårdere straf end den retten har fastsat: »(...) ikke nok med, at det er en straf i straffen jo, men det er måske endnu værre end fængselsstraffen« (Nicolai). At de interviewede oplever, at selve den uformelle straf $\mathrm{i}$ form af sagsbehandlingstiden er langt højere end den formelle straf fastsat af retten, får også betydning for deres oplevelse af kompensationen herfor: "Man bliver ved med at lade folk hænge, selvom systemet fucker op, og man fär rabat i den anden ende, det er et eller andet sted ligegyldigt (...) det kan på ingen måde opveje den tid, man har gået og ventet. Jeg vil hellere sige, at det var et plaster på såret« (John). Flere oplevede ligesom John, at vente i flere år på at modtage deres dom og få en symbolsk strafrabat på få måneder. Andre havde erfaringer med, at unødigt lange sagsbehandlingstider havde medført, at statskassen var blevet pålagt at betale sagens omkostninger. Fælles for dem var dog, at de reelt set ikke oplevede at modtage nogen form for kompensation, da de stadig var tynget af gæld til staten $\mathrm{fx}$ i form af konfiskationskrav.

Fortællingerne om den formelle kompensations manglende afspejling af den uformelle straf går igen, når talen falder på kompensation for uberettiget langvarig sigtelse: »Jamen altså, hvad skal jeg sige, det er jo fuldstændig grotesk. Jeg fik en erstatning på 50.000 kr. for uberettiget langvarig sigtelse og anklage, men fordi det er ... [en skattestraffesag], så har de [SKAT] også hjemmel til at tage alt, hvad der bliver udbetalt fra det offentlige« (Zakaria). Oplevelsen af ikke at få udbetalt erstatning er gennemgående blandt de interviewede, der har erfaret at være uberettiget strafforfulgt, da erstatning ikke er beskyttet mod modregning af gæld. De interviewedes erstatning er derimod gået til det offentliges regreskrav mod dem. De interviewede udtrykte en generel oplevelse af, at dømte bliver kompenseret mere rundhåndet end dem, der ender med at blive frifundet.

\section{Hvordan forholder vi os til de unødigt lange sagsbehandlingstider?}

Danmark blev i 2020 for tredje år i træk kåret som det land i verden med de bedste retsstatsgarantier, men ud fra de principper, som Danmark er blevet målt på, viser lange sagsbehandlingstider i straffesager sig at være et forhold, som vi langt fra kan være stolte af (World Justice Project). Problemet med sagsbehandlingstider, der ikke står i rimeligt forhold til sagens betydning og den forventede idømte straf, er dog ikke nyt. Et kort tilbageblik viser, at et udvalg nedsat i 1982 vedrørende bekæmpelse af økonomisk kriminalitet allerede dengang berettede om, at ressourceproblemer, herunder de lange berammelsestider, var et af retsvæsenets hovedproblemer. ${ }^{14}$ Omfattende økonomiske straffesager udgjorde på daværende tidspunkt et nyt kriminalitetsbillede, og

14. Betænkning nr. 1066, s. 22. 
disse sager var særligt ressourcekrævende og medførte en betydelig stigning i berammelsestiden ved domstolene i alle sagstyper. Udvalgets opgave var derfor bl.a. at overveje processuelle forenklinger, der kunne intensivere retsvæsnets indsats og nedbringe den samlede sagsbehandlingstid. I denne periode var der en erkendelse af, at en økonomisk saltvandsindsprøjtning af hele straffesagskæden næppe var på trapperne. Derfor indtog udvalget en pragmatisk tilgang til at løse de stigende sagsbehandlingstider. Udvalget vurderede, at der ikke var afgørende betænkeligheder ved at udvide adgangen til at beskære straffesager af ressourcemæssige grunde under forudsætning af, at de eksisterende kontrolmuligheder blev bevaret eller udbygget. Beskæring af straffesager skulle af økonomiske årsager og af hensyn til sigtede ske så tidligt i det straffeprocessuelle forløb som muligt. På den baggrund foreslog udvalget, at der blev indsat en ny bestemmelse i retsplejeloven, som gjorde det muligt for påtalemyndigheden helt eller delvist at opgive eller frafalde tiltale, hvis en sags gennemførelse ville medføre vanskeligheder, omkostninger eller behandlingstider, der ikke stod i rimeligt forhold til sagens betydning og den forventede idømte straf. ${ }^{15}$ Udvalget vedkendte, at en sådan tilgang ville betyde, at potentielle gerningspersoner ikke blev retsforfulgt og lovovertrædelser ikke blev efterforsket. Af denne grund anbefalede udvalget, at sådanne strafforfølgelsesmæssige kompromisser ikke blot blev et internt administrativt anliggende i Justitsministeriet, men derimod behandlet med åbenhed og fremgik af et lovforslag behandlet og vedtaget af folketinget. Loven blev indført som retsplejelovens $§ 723$ (lbk. 385/1987). ${ }^{16}$

Selvom situationen i dag på flere måder adskiller sig fra den i 1980'erne, så går udfordringerne med ressourcemangel og lange sagsbehandlingstider igen. Strafforståelsen og pragmatismen har dog forskubbet sig mærkbart. Hvor udvalget nedsat i 1982 udviste forståelse for det psykiske pres, som sigtede blev udsat for under straffesagernes lange sagsbehandlingstider, så er politiske argumenter for at tilgodese sigtedes situation i dag en sjældenhed. Hvor udvalget - hovedsagligt af økonomiske årsager - anbefalede at gøre kort proces og indgå strafforfølgelsesmæssige kompromisser så tidligt som muligt i det straffeprocessuelle forløb, så indgås disse kompromisser i form af kompensation for unødig lang sagsbehandlingstid i dag i den sidste del af forløbet, hvor sagerne allerede har kostet adskillige ressourcer og haft menneskelige omkostninger. ${ }^{17}$ På baggrund af en anbefaling fra Rigsrevisionen (2014) om at nedbringe den samlede sagsbehandlingstid af straffesagskæden, besluttede den daværende justitsminister i 2017 bl.a. at styrke fokusset på volds- og voldtægtssager samt sager om ulovlig besiddelse af våben på offentlig tilgængeligt sted (vvv-sager). Det betød, at retsvæsenet, der i for-

15. Betænkning nr. 1066, s. 189.

16. Bestemmelsen fremgår i dag af rpl. 722, nr. 5 .

17. Besvarelse af spørgsmål nr. 72 af 14. oktober 2019 fra Folketingets Retsudvalg til justitsministeren. 
vejen ressourcemæssigt var i knæ, skulle prioritere disse straffesagstyper. ${ }^{18}$ Den politiske prioritering skabte - ligesom tilfældet var tilbage i 1980'erne med tunge sager om økonomisk kriminalitet - en forskydning af sagsbehandlingstiderne på samtlige af domstolenes andre sagstyper. Men hvor man i 1980'erne mødte udfordringerne med de lange straffesager med en udbredt pragmatisme, så møder embedsmændene i Justitsministeriet i dag udfordringerne ved at opsætte mål- og resultatplaner for behandlingen af vvv-sager, indkalde til ekstraordinære koncernledelsesmøder om udviklingen i målopfyldelse og igangsætte midlertidige indberetningsordninger (Justitsministeriet 2018b). Trods disse initiativer er problemet vedvarende, og pilen peger fortsat på retsvæsenets ressourcemangel som hovedårsag hertil. Med den netop indgåede flerårsaftale om politiets og anklagemyndighedens økonomi for 2021-2023 tilføres der ressourcer til politi og anklagemyndighed for at mindske sagsbunkerne og sikre kortere sagsbehandlingstider (Justitsministeriet 2020). Domstolene er dog ikke på tilsvarende vis blevet tilgodeset økonomisk, hvorfor det er svært at se, hvordan en flaskehals kan undgås, og Danmarks internationale forpligtelser overholdes. Politikerne er tydelige omkring, at vvv-sager, som fremadrettet vil blive erstattet af sager om personfarlig kriminalitet, skal underlægges et skærpet fokus og prioriteres i straffesagskæden (Justitsministeriet 2020, s. 21). Det samme fokus har politikerne imidlertid ikke, når det kommer til håndteringen af de ikke-prioriterede straffesager.

De nye tiltag for at nedbringe straffesagers sagsbehandlingstid, som fremgår af flerårsaftalen, inkluderer bl.a. en indskrænkning af sigtedes ret til sammenlægning af straffesager, og som det blev forsøgt i 1980'erne, vil man atter forsøge sig med at udvide anklagemyndighedernes muligheder for at tilskære straffesager af ressourcemæssige grunde, når det ikke har væsentlig betydning for den forventede strafudmåling. Denne tilgang kan potentielt medføre flere straffesager, der skal behandles hos domstolene, ligesom der kan blive lovovertrædelser, som ikke vil blive retsforfulgt (Justitsministeriet 2021a). Selvom der i forslaget er tale om processuelle forenklinger, så er det svært at drage yderligere sammenligninger til 1980'ernes pragmatiske tilgang til reduceringen af de lange sagsbehandlingstider - ligesom det er svært at identificere 1980'ernes forståelse for sigtedes situation i flerårsaftalen. Aftalen lægger nemlig yderligere op til en markant udvidelse af mulighederne for udeblivelsesdomme. Dette sker bl.a. ved at skærpe dokumentationskravene for lovligt forfald, ligesom man endnu engang vil udvide rettens adgang til at fremme visse straffesager til dom uden sigtedes fremmøde og samtykke. Ud fra et retssikkerhedsmæssigt perspektiv vækker flere af initiativerne således bekymring, da de bl.a. vil medføre, at flere straffesager vil blive behandlet af retten uden sigtedes forklaring. Alt tyder altså på, at tilgangen til at nedbringe de lange sagsbehandlingstider i straffesager fortsat vil bestå i at forskyde problemerne og dermed symptombehandle fremfor at give hele

18. Prioriteringen medførte retssikkerhedsmæssige kompromisser i form af afgræsning af det frie forsvarsvalg (Justitsministeriet 2018a, s. 2, 2018b). 
straffesagskæden den økonomiske saltvandsindsprøjtning, der var nødvendig i 1980'erne, og fortsat er påkrævet. Yderligere fremgår det tydeligt af de nyligt præsenterede initiativer, at nedbringelsen af sagsbehandlingstiden i straffesager bl.a. skal ske ved at indføre konsekvenstænkning overfor de sigtede, der udebliver fra et retsmøde i en straffesag uden lovlig grund (Justitsministeriet 2021b). Det er således svært at se, hvordan vi i Danmark får udvidet vores fokus, så vi ikke blot tilstræber rettidig og effektiv behandling af straffesager for at højne tilliden til retssystemet og tilgodese ofre og den politiske signalværdi heri, men at vi også anerkender, at unødigt lange sagsbehandlingstider medfører, at vi møder sigtede med omfattende uformelle straffe, inden de er blevet dømt - uformelle straffe, der i værste fald kan virke hindrende for et kriminalitetsfrit liv.

\section{Kontaktoplysninger}

Kasper Jørgensen:

Annette Olesen: aol@socsci.aau.dk

\section{Referencer}

Albright, S. \& Denq, F. (1996). »Employer attitudes towards hiring ex-offender.« The Prison Journal 76(2): 118-137.

https://doi.org/10.1177/0032855596076002002

Bourdieu, P. (1995). »Den biografirske illusion« Social kritik 36: 33-38.

Comfort, M. (2007). »Punishment Beyond the Legal Offender.«Annual Review of Law and Social Science 3(1): 271-296.

https://doi.org/10.1146/annurev.lawsocsci.3.081806.112829

Crewe, B., Hulley, S. \& Wright, S. (2017). "Swimming with the tide: Adapting to long-term« Imprisonment.« Justice Quarterly 34: 517-541. https://doi.org/10.1080/07418825.2016.1190394

Christie, N. (2004). »Straffen som problem.« Nordisk tidsskrift for kriminalvidenskab 91(4): 302-310.

https://doi.org/10.7146/ntfk.v91i4.71602

Freeman, S. \& Seymour, M. (2010). »'Just Waiting': The Nature and Effect of Uncertainty on Young People in Remand Custody in Ireland."Youth Justice 10(2): 126-142. https://doi.org/10.1177/1473225410369298

Goffman, E. (1961). »Asylums: Essays on the Social Situation of Mental Patients and Other Inmates." Garden City, N.Y.: Vintage Books.

Harding, T. \& Zimmermann, E. (1989). „Psychiatric symptoms, cognitive stress and vulnerability factors. A study in a remand prison." British Journal of Psychiatry 155: 36-43. https://doi.org/10.1192/bjp.155.1.36

Hayes, D. (2018). »Proximity, pain, and State punishment.« Punishment \& Society 20: 235-254. https://doi.org/10.1177/1462474517701303

Hulley, S., Crewe, B. \& Wright, S. (2016). »Re-Examining the Problems of Long-Term Imprisonment« British Journal of Criminology 56: 769-792.

https://doi.org/10.1093/bjc/azv077

Jørgensen, K., Hansen, H. F., Oxlund, B. H. \& Philipsen, M. N. (2020). »Man føler sig magtesløs.»Aalborg Universitet. 
Keene, D. E., Smoyer, A. B. \& Blankenship, K. M. (2018). »Stigma, Housing and Identity after Prison.«The Sociological review 66: 799-815. https://doi.org/10.1177/0038026118777447

Kotova, A. (2020). „Beyond Courtesy Stigma: Towards a Multi-Faceted and Cumulative Model of Stigmatisation of Families of People in Prison. «Forensic Science International: Mind and Law 1. https://doi.org/10.1016/j.fsiml.2020.100021

Laursen, J., Crewe, B. \& Mjåland, K. (2019). »It's like a sentence before the sentence' - Exploring the pains and possibilities of waiting for imprisonment. « The British Journal of Criminology 60: 363-381. https://doi.org/10.1093/bjc/azz042

Lorenzen, P., Christoffersen, J., Holst-Christensen, N., Kessing, V. P., Schaumburg-Müller. \& Vedsted-Hansen, J. (2003). »Den Europæiske Menneskerettighedskonvention.« Juristog Økonomforbundet.

Martinez, S. M. (2011). »Employer perceptions about hiring released prisoners with a criminal history.« Minnesota: Capella University.

Mattingly, C. (2014). »Moral Laboratories: Family Peril and the Struggle for a Good Life.» Oakland, California: University of California Press.

https://doi.org/10.1525/california/9780520281196.001.0001

Merry, S. E. (1990). „Getting Justice and Getting Even.« Chicago: University of Chicago Press.

Mesmaecker, V. D. (2014). »Perceptions of Criminal Justice.« New York: Routledge. https://doi.org/10.4324/9781315885964

Neustatter, A. (2002). »Locked In. Locked Out. The Experience of Young Offenders out of Society and in Prison."London: Calouste Gulbenkian Foundation.

Noaks, L. \& Wincup, E. (2017). „Criminological research Understanding qualitative methods.» London: SAGE Publications. https://doi.org/10.4135/9781473982802

Olesen, A. (2013). »Løsladt og gældsat.« Jurist- og Økonomforbundet.

Orjiakor, C. T., Ugwu, D., Eze, E. J., Ugwu I. L., Peace N. \& Onu I. D. (2017). »Prolonged incarceration and prisoners' wellbeing: livid experiences of awaiting trial/pre-trial/remand prisoners in Nigeria. International Journal of Qualitative Studies on Health and Wellbeing 9: 2-16. https://doi.org/10.1080/17482631.2017.1395677

Pager, D., Western, B. \& Sugie, N. (2009). "Sequencing Disadvantage: Barriers to Employment Facing Young Black and White Men with Criminal Records." The ANNALS of the American Academy of Political and Social Science 623: 195-213. https://doi.org/10.1177/0002716208330793

Peel, D. (2013). „Clutching at Life, Waiting to Die. The Experience of Death Row Incarceration. W Western Criminology Review 14: 61-72.

Raphael, S. (2011). »Incarceration and Prisoner Reentry in the United States. "The ANNALS of the American Academy of Political and Social Science 635: 192-215. https://doi.org/10.1177/0002716210393321

Sarat, A. (1990). „The Law is All Over: Power, Resistance, and the Legal Consciousness of the Welfare Poor." Yale Journal of Law and the Humanities 2: 343-379.

Sexton, L. (2015). »Penal Subjectivities: Developing a Theoretical Framework for Penal Consciousness." Punishment \& Society 17: 114-136.

https://doi.org/10.1177/1462474514548790

Shammas, V. L. (2014). »The Pains of Freedom: Assessing the Ambiguity of Scandinavian Penal Exceptionalism on Norway's Prison Island.« Punishment \& Society 16: 104-123. https://doi.org/10.1177/1462474513504799

Sheppard, A. \& Ricciardelli, R. (2020). »Employment after Prison: Navigating Conditions of Precarity and Stigma.« European journal of probation 12: 34-52.

https://doi.org/10.1177/2066220320908251 
Smith, S. P. (2014). »When the Innocent are Punished. Palgrave Studies in Prisons and Penology.« London: Palgrave Macmillan.

https://doi.org/10.1057/9781137414298

Sykes, G. M. (1958). »The Society of Captives.« New Jersey: Princeton University Press.

Toftegaard, N. G. (2004). »Straffesagens gang« (3.eds.). Jurist- og Økonomforbundet.

Tranæs, T. \& Geerdsen, P. L. (2008). »Forbryderen og samfundet.« Kbh.: Gyldendal.

Turnbull, S. (2015). »'Stuck in the Middle': Waiting and uncertainty in immigration detention.» Time \& Society 25: 61-79.

https://doi.org/10.1177/0961463X15604518

\section{Rapporter m.v.}

Institut for Menneskerettigheder (2013). »Retfærdig rettergang.« Kbh.

Justitsministeriet (2018a). »Hurtigere vej fra forbrydelse til fængsel.« Kbh.

Justitsministeriet (2018b). „Orientering om sagsbehandlingstiderne i volds- og voldtægtssager samt sager om ulovlig besiddelse af våben på offentlig tilgængeligt sted i 2017.« Sagsnr. 2018-0282-028.

Justitsministeriet (2020). »Aftale om politiets og anklagemyndighedens økonomi 20212023.« Kbh.

Justitsministeriet (2021a). »Overblik over initiativer.» Kbh.

https://www.justitsministeriet.dk/wp-content/uploads/2021/02/Overblik-over-initiativerstraffesagskaeden.pdf

Justitsministeriet (2021b). »Justitsministeren vil skærpe kursen mod tiltaltes udeblivelser i straffesager.«Pressemeddelelse 15. februar 2021. Kbh.

https://www.justitsministeriet.dk/pressemeddelelse/justitsministeren-vil-skaerpe-kursenmod-tiltaltes-udeblivelser-i-straffesager/

Rigsrevisionen (2014). »Beretning Statsrevisorerne om straffesagskæden.« Kbh.

Rigsrevisionen (2017). »Rigsrevisionens notat om beretning om straffesagskæden.« Kbh. Rigsrevisionen (2019). »Rigsrevisionens notat om beretning om straffesagskæden.« Kbh. Statsrevisorerne (2014). »Beretning om straffesagskæden.« nr. 9/2013. Kbh.

World Justice Project (2020). »Rule of Law Index 2020.« USA. 